\title{
Zona Kemampuan Geologi Teknik untuk Pemukiman Daerah Prambanan dan Sekitarnya Kecamatan Prambanan, Kabupaten Sleman, Daerah Istimewa Yogyakarta
}

\author{
Wisnu Aji Dwi Kristanto ${ }^{1)}$, I Gde Budi Indrawan ${ }^{2)}$, Salam Via Febriyanti ${ }^{1)}$ \\ 1) Teknik Lingkungan, Fakultas Teknologi Mineral, UPN Veteran Yogyakarta \\ 2) Teknik Geologi, Fakultas Teknik, Universitas Gadjah Mada \\ * email korespondensi: wisnuaji@upnyk.ac.id
}

\begin{abstract}
ABSTRAK
Kebutuhan lahan untuk pemukiman meningkat seiring dengan pertumbuhan penduduk yang kian pesat. Penyediaan lahan pemukiman yang baik, wajib memperhatikan kemampuan lahan berdasarkan kondisi geologi teknik untuk memastikan kesesuaian lahan. Penelitian ini bertujuan untuk mengetahui kemapuan geologi teknik untuk kesesuaian lahan pemukiman. Penelitian zona kemampuan geologi teknik untuk pemukiman di daerah Kecamatan Prambanan, Kabupaten Sleman, Daerah Istimewa Yogyakarta dibatasi koordinat 442800mE-449800mE dan 9136500mN$9142000 \mathrm{mN}$ dengan luas daerah penelitian $38,5 \mathrm{~km}^{2}$. Penelitian zona kemampuan geologi teknik untuk pemukiman berupa rumah sederhana dengan pondasi dangkal berukuran $1 \times 1 \mathrm{~m}^{2}$ disusun berdasarkan analisis peta daya dukung batuan dan tanah, kemudahan penggalian, kemiringan lereng, kedalaman muka airtanah, dan kerentanan bencana geologi daerah penelitian melalui analytic hierarchy process. Hasil penelitian kempampuan geologi teknik untuk pemukiman dibagi menjadi: daerah perbukitan memiliki nilai kemampuan geologi teknik untuk pemukiman sangat rendah, rendah dan menengah, sedangkan daerah dataran memiliki nilai kemampuan geologi teknik untuk pemukiman tinggi pada sebagian besar area, menengah di daerah sekitar sungai besar, dan kemampuan geologi teknik sangat rendah untuk daerah sepanjang sungai besar.
\end{abstract}

Kata Kunci: analytic hierarchy process; kemampuan geologi teknik; pemukiman

\begin{abstract}
Land requirements for settlements are increasing along with increasingly rapid population growth. Provision of proper settlement, must pay attention to the ability of lands based on engineering geology conditions to ensure land suitability. This study aims to determine the engineering geology capability for suitability of residential land. Research on the engineering geology capability zone for settlements in the Prambanan Subdistrict, Sleman Regency, Special Region of Yogyakarta, is limited by coordinates $442800 \mathrm{mE}-449800 \mathrm{mE}$ and $9136500 \mathrm{mN}-9142000 \mathrm{mN}$ with an area of $38.5 \mathrm{~km} 2$. Research of the engineering geology capability zone for settlements is in the form of a simple house with a shallow foundation measuring $1 \times 1 \mathrm{~m}^{2}$ based on analysis of rock and soil carrying capacity, ease of excavation, slope, groundwater depth, and vulnerability of the geological disaster of the study area through analytic hierarchy process. The results of the engineering geological capability research for settlements are divides into: hilly areas have the geotechnical capability for settlements values from very low to medium, while the plains have the value of geological capability for settlements high in most areas, medium in the area around large rivers, and very low for areas along major rivers.
\end{abstract}

Keywords: analytic hierarchy process; engineering geology capability; settlement

\section{PENDAHULUAN}

Menurut data Badan Pusat Statistik (BPS) (2015), kepadatan penduduk Daerah Istimewa Yogyakarta terutama di Kabupaten Sleman mencapai 1.939 jiwa/ $\mathrm{km}^{2}$. Di samping itu pesatnya pertumbuhan penduduk di Kabupaten Sleman yang mencapai 17.775 jiwa/tahun menurut data BPS tujuh tahun terakhir (2007-2013). Seiring hal tersebut mendorong diperlukannya perencanaan pengembangan lahan terutama untuk pemukiman dan pemerataan penduduk yang baik.

Menurut data BPS (2015), daerah Prambanan memiliki luas wilayah 413,50 km² dengan kepadatan penduduk mencapai $121,61 \mathrm{jiwa} / \mathrm{km}^{2}$ atau $16 \mathrm{kali}$ lipat lebih rendah dari kepadatan penduduk Kabupaten Sleman secara keseluruhan. Dengan kepadatan penduduk yang rendah, daerah Prambanan memungkinkan untuk pengembangan lahan pemukiman.

Menurut Kristanto dkk. (2018 dan 2020), daerah Prambanan memiliki morfologi berupa bukit, perbukitan, lereng terjal (gawir), dan dataran dengan litologi berupa tuf, lapili, batupasir, endapan pasir, dan endapan lempung dengan tingkat pelapukan bervariasi. Hal ini menyebabkan daerah Prambanan memiliki potensi bencana alam seperti tanah longsor di beberapa area. Oleh sebab itu diperlukan penyelidikan guna mendukung analisis kemampuan geologi teknik untuk pemukiman. 


\section{METODE}

Penelitian kemampuan geologi teknik untuk pemukiman dilakukan dengan pemetaan lapangan dan pengolahan data sekunder terkait daerah penelitian serta analisa lab. Data hasil pemetaan lapangan dan pengolahan data sekunder yang diolah menjadi parameter-parameter terkait penelitian dianalisis menggunakan metode Analytic Hierarchy Process (AHP) (Saaty, 1977) dan dilakukan overlay dengan perangkat lunak ArcGIS 10. Parameter-parameter geologi yang berkaitan dengan kemampuan geologi teknik untuk pemukiman berupa daya dukung batuan dan tanah, kemiringan lereng, bencana beraspek geologi, kemudahan penggalian, kedalaman muka airtanah.

\section{a. Parameter Daya Dukung Batuan Dan Tanah}

Parameter daya dukung material (batuan dan tanah) diklasifikasikan berdasarkan daya dukung material terhadap beban konstruksi bangunan dalam satu meter persegi. Hal ini berdasar Pedoman Perencanaan Pembebanan untuk Rumah dan Gedung (Departermen Pekerjaan Umum, 1987). Nilai beban konstruksi bangunan ini dibandingkan dengan daya dukung material serta tingkat pelapukan batuan. Klasifikasi daya dukung material dibagi menjadi:

- $\quad$ Batuan segar-tanah padat dengan Qall $>1967 \mathrm{~kg} / \mathrm{m}^{2}$.

- $\quad$ Tanah padat dengan Qall $<1967 \mathrm{~kg} / \mathrm{m}^{2}$.

- Tanah lunak dengan Qall $<1967 \mathrm{~kg} / \mathrm{m}^{2}$.

\section{b. Parameter Kemudahan Penggalian}

Kriteria kemudahan penggalian digunakan untuk mengetahui tingkat kemudahan penyiapan lahan dan pekerjaan dengan penggalian di wilayah daerah Prambanan dan sekitarnya. Klasifikasi yang digunakan dalam kriteria ini mengacu pada diagram tingkat kemudahan penggalian massa batuan oleh Pettifer dan Fookes (1994) dalam Gurocak dkk. (2007). Klasifikasi ini dibuat berdasarkan perbandingan uji kekuatan batuan menggunakan point load dengan spasi bidang diskontinuitas dalam massa batuan pada Gambar 1. Klasifikasi parameter ini disederhanakan menjadi tiga kelas yaitu:

- $\quad$ Mudah digali

- $\quad$ Sulit digali-luar biasa sulit dibajak

- $\quad$ Perlu peledakan

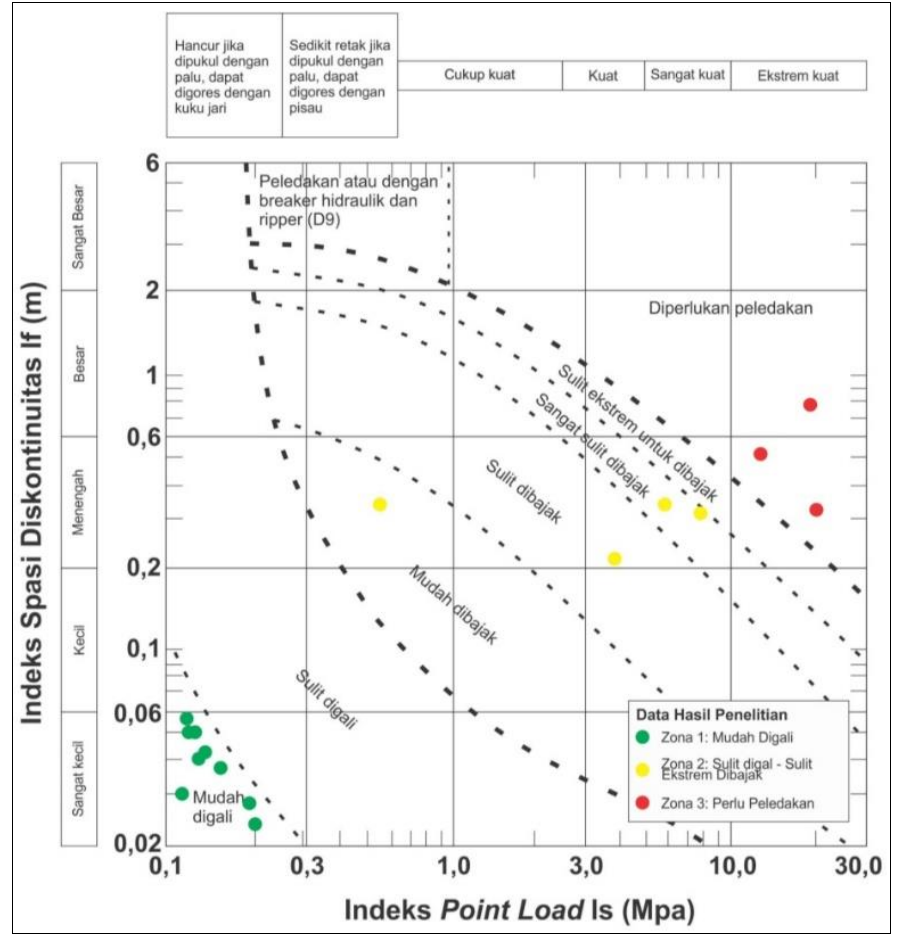

Gambar 1. Diagram Kemudahan Penggalian Massa Batuan Sumber: Pettifer dan Fookes, (1994) dalam Gurocak dkk. (2007)

\section{c. Parameter Kemiringan Lereng}

Penentuan parameter kemiringan lereng berdasarkan sudut workability untuk pekerjaan rekayasa yang dikemukakan oleh Novianto dkk. (1997). Berdasarkan sudut workability kemiringan lereng dapat diklasifikasikan menjadi tiga kelas yaitu $<8^{\circ}, 8^{\circ}-30^{\circ}$, dan $>30^{\circ}$. 


\section{d. Parameter Kedalaman Muka Airtanah}

Kedalaman muka airtanah diperlukan untuk mengetahui pengaruh airtanah terhadap kestabilan tanah. Tanah dengan kondisi jenuh air akan memiliki tingkat kestabilan yang lebih rendah dibanding dengan tanah kering. Klasifikasi kedalaman muka airtanah didasarkan pada konstruksi permukaan seperti pondasi dangkal dan septic tank yang terbagi menjadi tiga kelas yaitu <1 $\mathrm{m}, 1-3 \mathrm{~m}$, dan $>3 \mathrm{~m}$.

\section{e. Parameter Kerentanan Bencana Geologi}

Daerah Prambanan dan sekitarnya memiliki potensi bencana geologi diantaranya longsor, banjir, dan gempa bumi. Hal ini didukung oleh deretan perbukitan dengan lereng yang bergelombang kuat yang merupakan aspek penting longsor (Nugroho dkk., 2020), serta dataran dengan sungai-sungai besar yang membelahnya didukung iklim tropis dengan curah hujan tinggi. Selain itu daerah Prambanan masih terpengaruh jalur penunjaman di selatan Pulau Jawa. Oleh karena itu kriteria kerentanan bencana geologi dianalisis dari data sekunder keluaran dinas terkait dan dasar peta satuan geologi teknik daerah penelitian.

Wilayah dengan ancaman lebih dari satu macam ancaman bencana geologi masuk dalam kategori kerentanan tinggi, wilayah dengan satu ancaman bencana geologi masuk dalam kategori sedang, dan wilayah dengan tidak ada ancaman bencana geologi masuk dalam kategori ringan atau netral.

\subsection{Analytic Hierarchy Process}

Lima parameter yang digunakan dalam penelitian di diuraikan dalam sub-parameter dan dibagi sesuai bobot masingmasing parameter menggunakan metode Analytic Hierarchy Process. Analisis metode AHP lima parameter kemampuan geologi teknik untuk pemukiman yang menghasilkan bobot dan skor seperti dalam Tabel 1.

Tabel 1. Nilai Skor Akhir Tiap Parameter Berdasarkan Penelitian

\begin{tabular}{|c|c|c|c|c|c|}
\hline Parameter & Sub-Parameter & Kategori & Kelas & Bobot & Skor \\
\hline \multirow{3}{*}{ Daya dukung batuan dan tanah } & $\begin{array}{l}\text { Batuan segar-tanah padat dengan Qall >1967 } \\
\qquad \mathrm{kg} / \mathrm{m}^{2}\end{array}$ & Baik & 3 & \multirow{3}{*}{0,22} & 0,66 \\
\hline & Tanah padat dengan Qall $<1967 \mathrm{~kg} / \mathrm{m}^{2}$ & Buruk & 2 & & 0,44 \\
\hline & Tanah lunak dengan Qall $<1967 \mathrm{~kg} / \mathrm{m}^{2}$ & $\begin{array}{l}\text { Sangat } \\
\text { buruk }\end{array}$ & 1 & & 0,22 \\
\hline \multirow{3}{*}{ Kemudahan penggalian } & Mudah digali & Baik & 3 & \multirow{3}{*}{0,08} & 0,24 \\
\hline & Sulit digali-luar biasa sulit dibajak & Cukup & 2 & & 0,16 \\
\hline & Perlu peledakan & Buruk & 1 & & 0,08 \\
\hline \multirow{3}{*}{$\begin{array}{c}\text { Kemiringan lereng terhadap } \\
\text { kemudahan pengerjaan konstruksi } \\
\left({ }^{\circ}\right)\end{array}$} & $<8$ & Mudah & 3 & \multirow{3}{*}{0,14} & 0,42 \\
\hline & $8-30$ & Sulit & 2 & & 0,28 \\
\hline & $>30$ & $\begin{array}{l}\text { Sangat } \\
\text { sulit }\end{array}$ & 1 & & 0,14 \\
\hline \multirow{3}{*}{$\begin{array}{l}\text { Kedalaman muka airtanah } \\
\text { terhadap pondasi dan septic tank } \\
\text { (m) }\end{array}$} & $>3$ & Baik & 3 & \multirow{3}{*}{0,17} & 0,51 \\
\hline & $1-3$ & Cukup & 2 & & 0,34 \\
\hline & $<1$ & Buruk & 1 & & 0,17 \\
\hline \multirow{3}{*}{ Kerentanan bencana geologi } & Rendah & Netral & 3 & \multirow{3}{*}{0,39} & 1,17 \\
\hline & Sedang & $\begin{array}{l}\text { Rentan } \\
\text { sedang }\end{array}$ & 2 & & 0,78 \\
\hline & Tinggi & $\begin{array}{c}\text { Rentan } \\
\text { tinggi }\end{array}$ & 1 & & 0,39 \\
\hline
\end{tabular}

Kemampuan geologi teknik untuk pemukiman pada penelitian ditentukan dengan pembagian rentang skor akhir dari akumulasi masing-masing parameter tertinggi dan terendah pada Tabel 1. Skor akhir dibagi dalam empat kelompok rentang zona dengan parameter yang paling berpengaruh sesuai pedoman Analytic Hierarchy Process yang telah disesuaikan dengan penelitian sebagai berikut:

$\begin{array}{ll}\text { Kemampuan tinggi } & : \geq 2,60 \\ \text { Kemampuan menengah } & : 2,20-2,59 \\ \text { Kemampuan rendah } & : 1,80-2,19 \\ \text { Kemampuan sangat rendah } & :<1,80\end{array}$

Zona kemampuan geologi teknik tinggi merupakan zona yang paling direkomendasikan untuk dikembangkan menjadi wilayah pemukiman karena memiliki karakteristik geologi teknik yang baik untuk pondasi bangunan dan mudah untuk dikerjakan.

Zona kemampuan geologi teknik menengah merupakan zona yang cukup baik untuk dikembangkan menjadi wilayah pemukiman namun memerlukan penyelidikan detail sebelum dikembangkan menjadi wilayah pemukiman. 
Zona kemampuan geologi teknik rendah merupakan zona yang tidak disarankan namun diijinkan untuk dikembangkan menjadi wilayah pemukiman dengan penyelidikan detail dan pekerjaan rekayasa terlebih dahulu sebelum dikembangkan menjadi wilayah pemukiman.

Zona kemampuan geologi teknik sangat rendah merupakan zona yang tidak diijinkan dan harus dihindari untuk dikembangkan menjadi wilayah pemukiman karena memiliki karakteristik geologi teknik yang buruk dan memiliki kerentanan bencana.

\section{HASIL DAN PEMBAHASAN}

\subsection{Parameter Kemampuan Geologi Teknik Untuk Pemukiman}

Berdasarkan pemetaan dan analisis data sekunder diperoleh hasil lima parameter pendukung kemampuan geologi teknik untuk pemukiman berupa:

\section{a. Daya Dukung Batuan dan Tanah}

Peta daya dukung batuan dan tanah didasarkan atas peta geologi teknik yang dikemukakan oleh Kristanto dkk. (2018) pada Gambar 2 dikonversi kedalam daya dukung batuan dan tanah terhadap beban konstruksi bangunan sederhana sesuai satuan geologi teknik daerah penelitian yang dapat dilihat pada Gambar 3 .

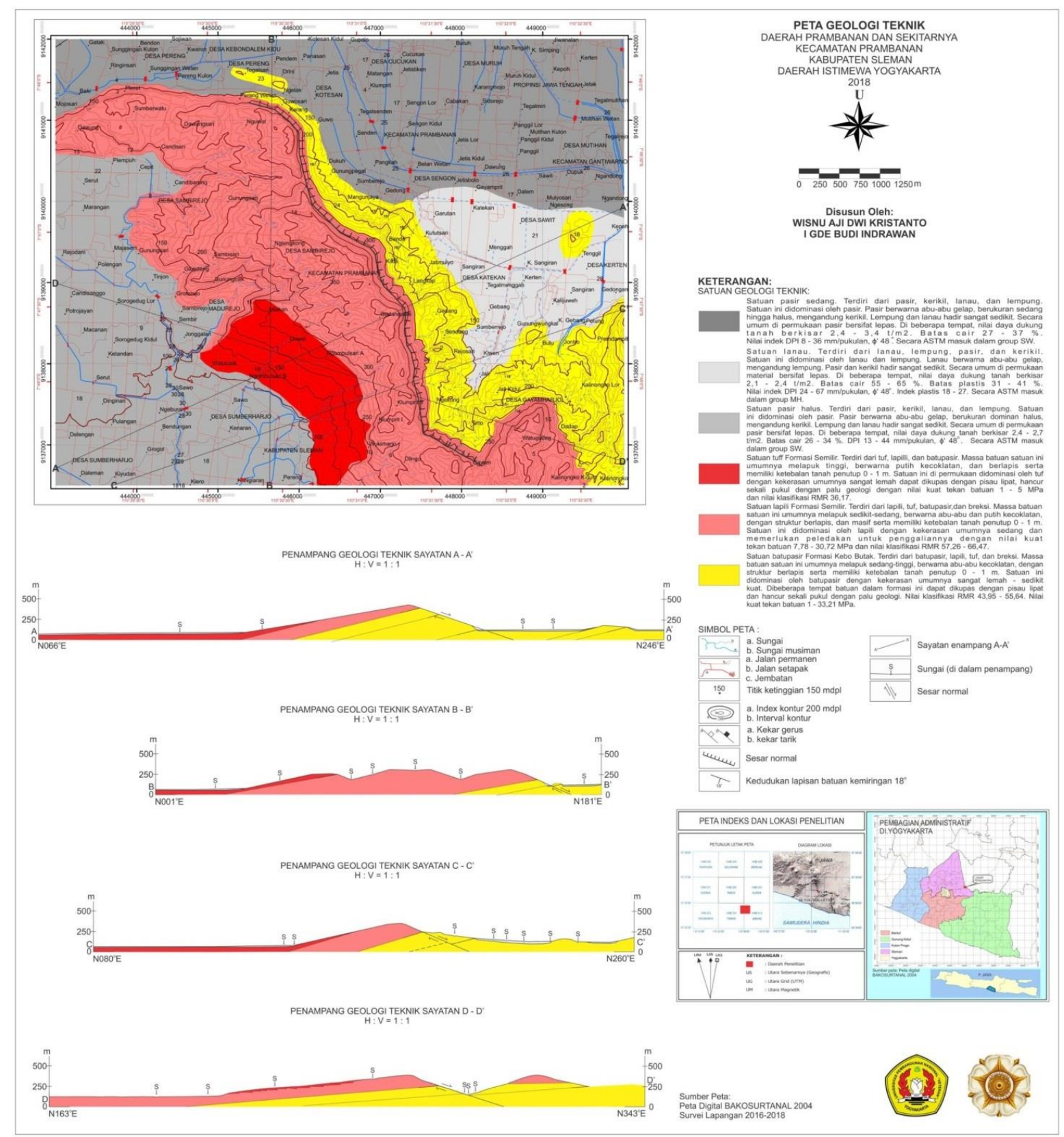

Gambar 2. Peta Geologi Teknik Daerah Prambanan dan Sekitarnya Oleh Kristanto dkk. (2018) 


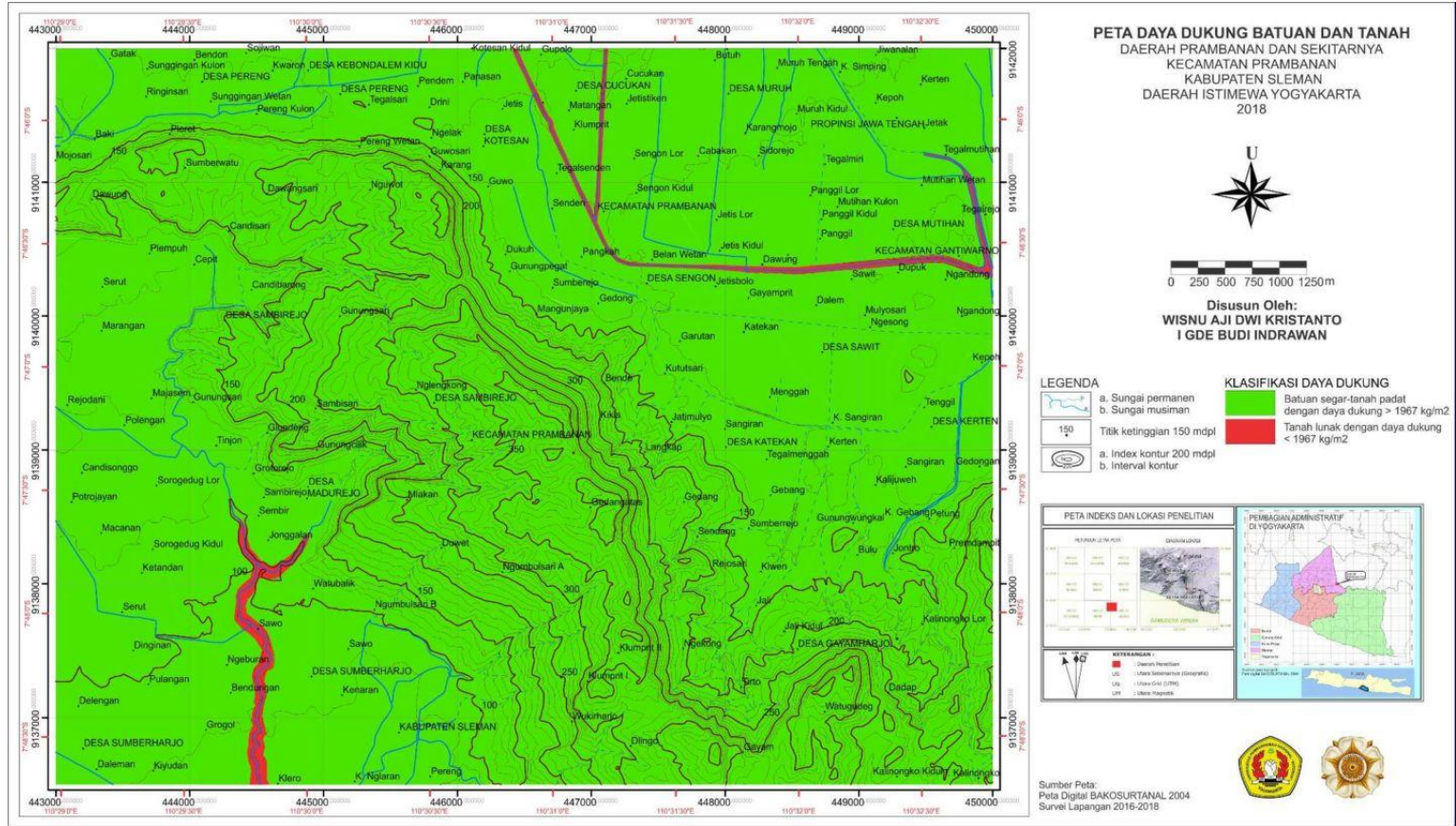

Gambar 3. Peta Daya Dukung Batuan dan Tanah

Daerah Prambanan dan sekitarnya mayoritas memiliki daya dukung batuan dan tanah dengan nilai lebih besar dari 1967 $\mathrm{kg} / \mathrm{m}^{2}$ yang mencakup $97 \%$ luas keseluruhan daerah penelitian. Daerah dengan daya dukung batuan dan tanah lebih dari $1967 \mathrm{~kg} / \mathrm{m}^{2}$ termasuk dalam satuan batupasir, lapili, tuff, pasir sedang, dan sebagian besar lanau dan pasir halus. Sedangkan 3\% luas lainnya memiliki nilai daya dukung batuan dan tanah kurang dari $1967 \mathrm{~kg} / \mathrm{m}^{2}$ yang meliputi sepanjang sungai besar dan sepadan sungai di daerah satuan lanau dan pasir halus seperti pada Gambar 3. Nilai daya dukung batuan dan tanah yang lebih dari $1967 \mathrm{~kg} / \mathrm{m}^{2}$ mendukung untuk konstruksi rumah sederhana.

\section{b. Kemudahan Penggalian}

Hasil dari pengujian dan pengamatan lapangan di daerah penelitian terbagi menjadi 3 zona: mudah digali, sulit digali hingga sulit ekstrim dibajak, dan perlu peledakan dapat dilihat pada Gambar 4.

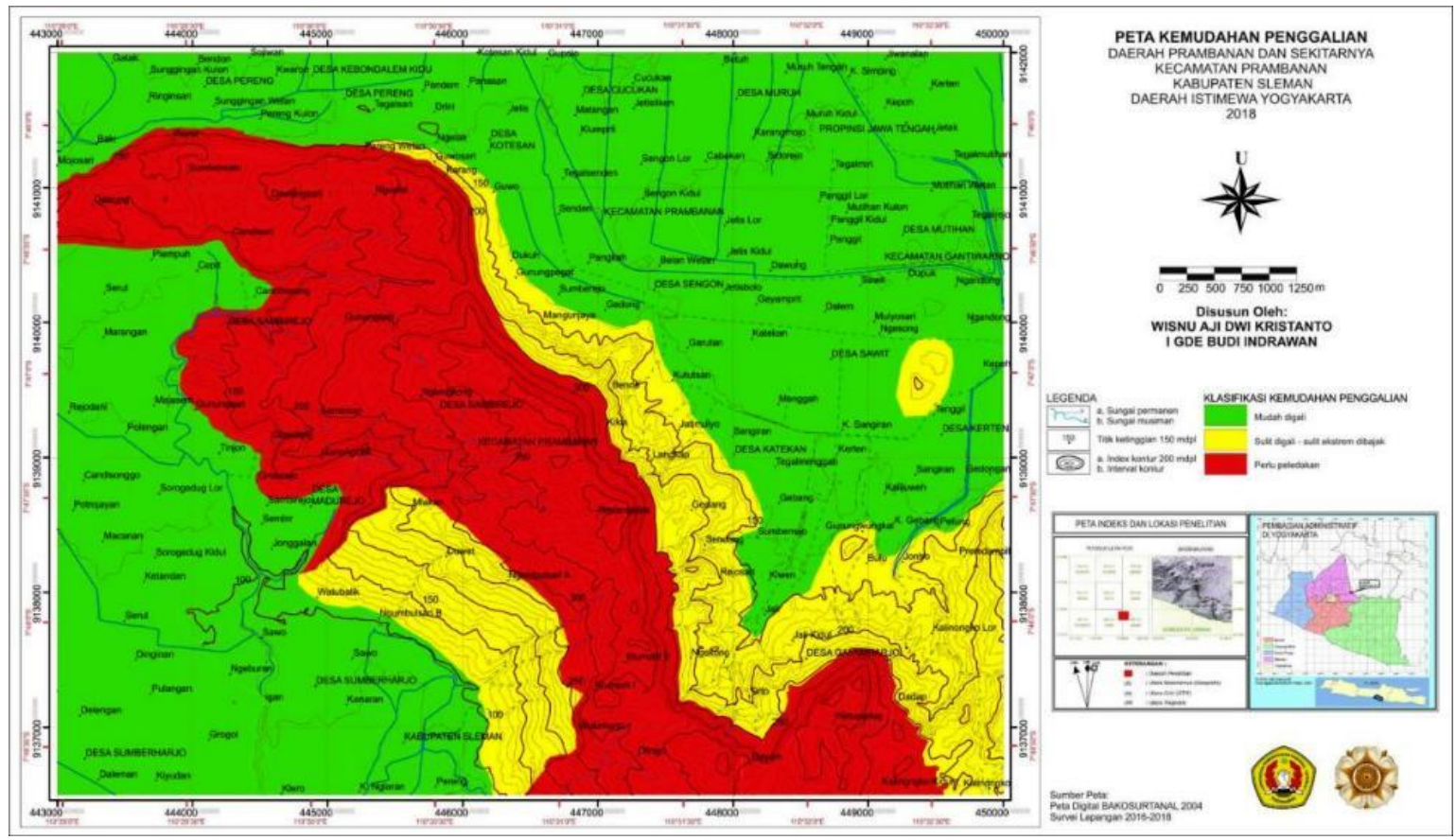

Gambar 4. Peta Kemudahan Penggalian 
Daerah dengan tingkat kemudahan penggalian mudah digali meliputi wilayah landaian yang didominasi dengan satuan batuan berupa material lepas. Sedangkan daerah dengan tingkat kemudahan penggalian sulit digali sampai dengan sulit ekstrem dibajak meliputi wilayah lereng timur dan barat dengan satuan batuan berupa batupasir dan tuff. Daerah dengan tingkat kemudahan penggalian perlu peledakan meliputi wilayah perbukitan tengah dengan satuan batuan lapili. Semakin mudah digali, daerah tersebut akan semakin mudah dilakukan rekayasa pekerjaan konstruksi.

\section{c. Kemiringan Lereng}

Dari analisis yang dilakukan diperoleh keberagaman kemiringan lereng yang terbagi menjadi tiga kelompok lereng yaitu: $<8^{\circ}, 8^{\circ}-30^{\circ}$, dan $>30^{\circ}$ dapat dilihat pada Gambar 5.

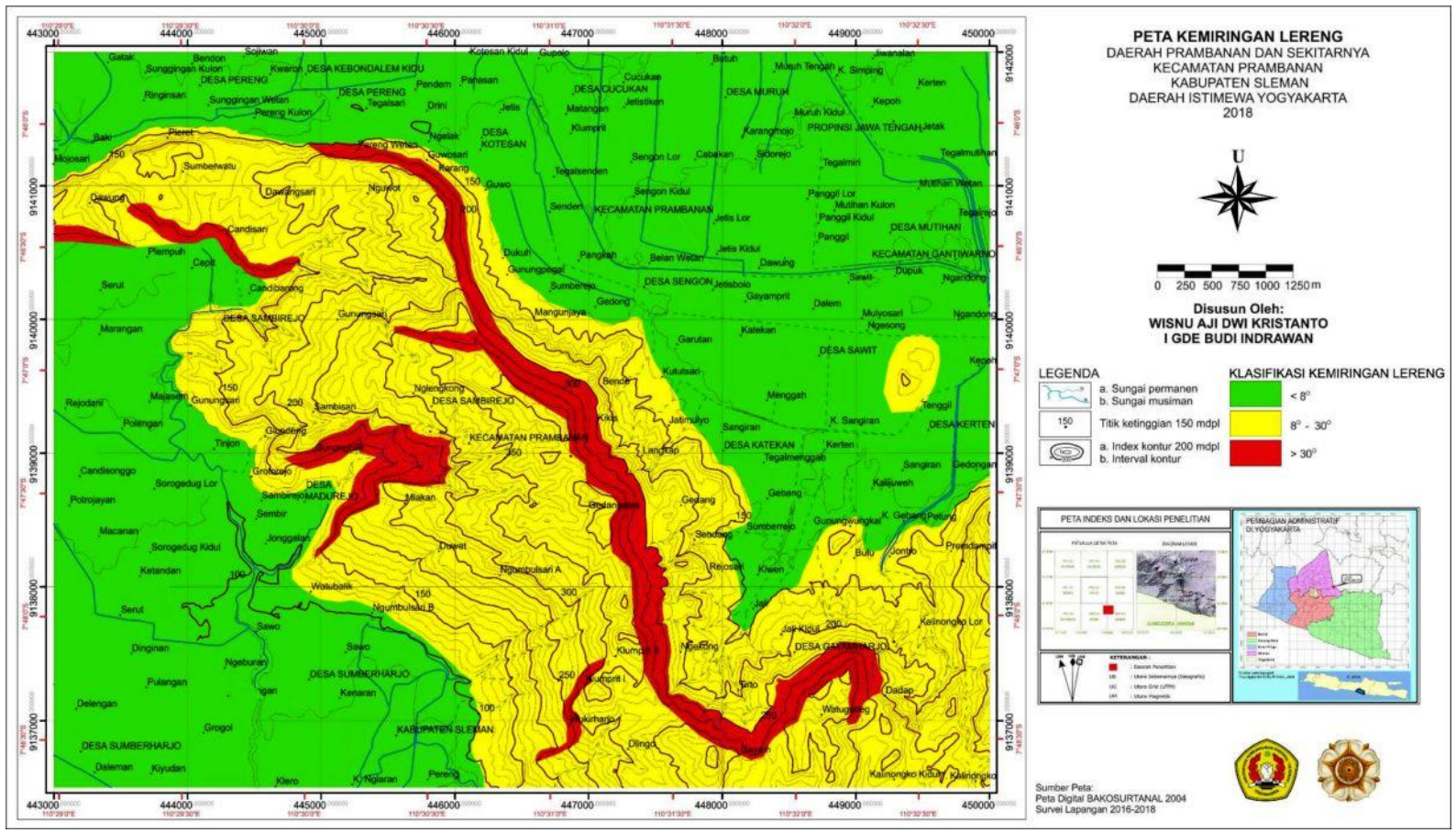

Gambar 5. Peta Kemiringan Lereng

Lereng dengan kemiringan lebih kecil dari $8^{\circ}$ meliputi daerah utara, timur, dan barat daerah penelitian yang menunjukan bahwa daerah tersebut cukup landai mencakup 50\% luas keseluruhan. Daerah dengan kemiringan lereng $8^{\circ}-30^{\circ}$ yang tergolong miring meliputi sebagian besar daerah perbukitan tengah dengan luas $42 \%$ dari keseluruhan luas daerah penelitian. Sedangkan daerah dengan kemiringan lereng lebih dari $30^{\circ}$ yang tergolong curam meliputi $8 \%$ dari luas keseluruhan daerah penelitian. Kemiringan lereng yang semakin landai, memungkinkan pekerjaan konstruksi semakin mudah.

\section{d. Kedalaman Muka Airtanah}

Daerah penelitian memiliki kedalaman muka airtanah $>3 \mathrm{~m}$ di daerah perbukitan dan sebagian besar dataran, kedalaman muka airtanah 1-3 $\mathrm{m}$ di sekitar sungai besar, dan kedalaman muka airtanah $<1 \mathrm{~m}$ di sepanjang sungai besar dapat dilihat pada Gambar 6. 


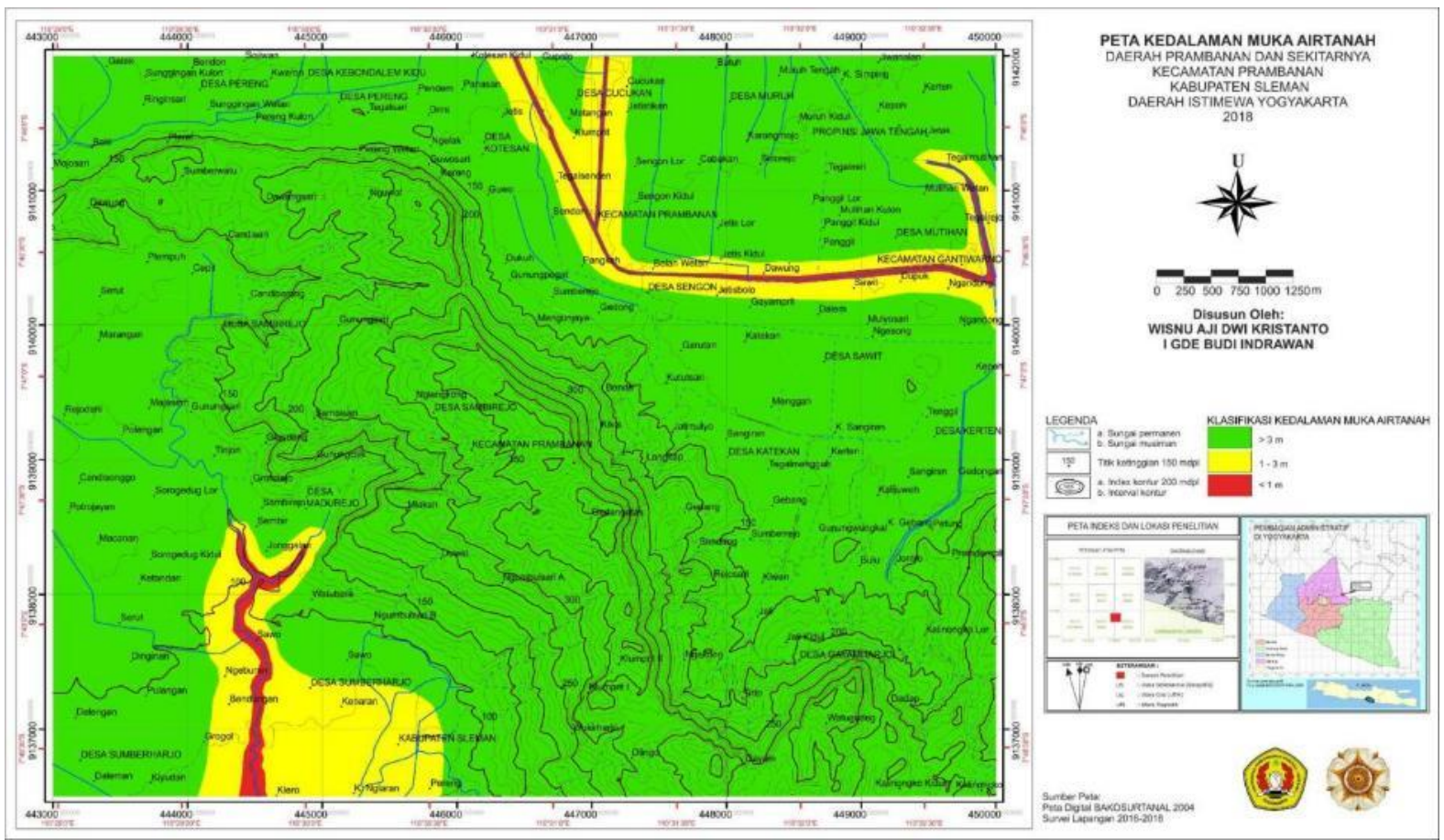

Gambar 6. Peta Kedalaman Muka Airtanah

Kedalaman muka airtanah berdasar kebutuhan kostruksi menunjukan 85\% daerah penelitian memiliki kedalaman muka airtanah yang mendukung konstruksi rumah sederhana dengan kedalaman lebih dari 3 meter. Sedangkan daerah dengan kedalaman kurang dari 3 meter meliputi wilayah sekitar sungai dan dataran banjir sungai besar di daerah penelitian mencakup $15 \%$ dari luas keseluruhan daerah penelitian. Wilayah dengan kedalaman muka airtanah dangkal ini tidak direkomendasikan untuk konstruksi rumah.

\section{e. Kerentanan Bencana Geologi}

Kerentanan bencana geologi daerah penelitian terbagi menjadi dua zona: zona kerentanan tinggi meliputi daerah lereng bagian timur dan utara serta daerah sungai besar, zona kerentanan sedang meliputi daerah dataran dan perbukitan bagian barat dapat dilihat pada Gambar 7.

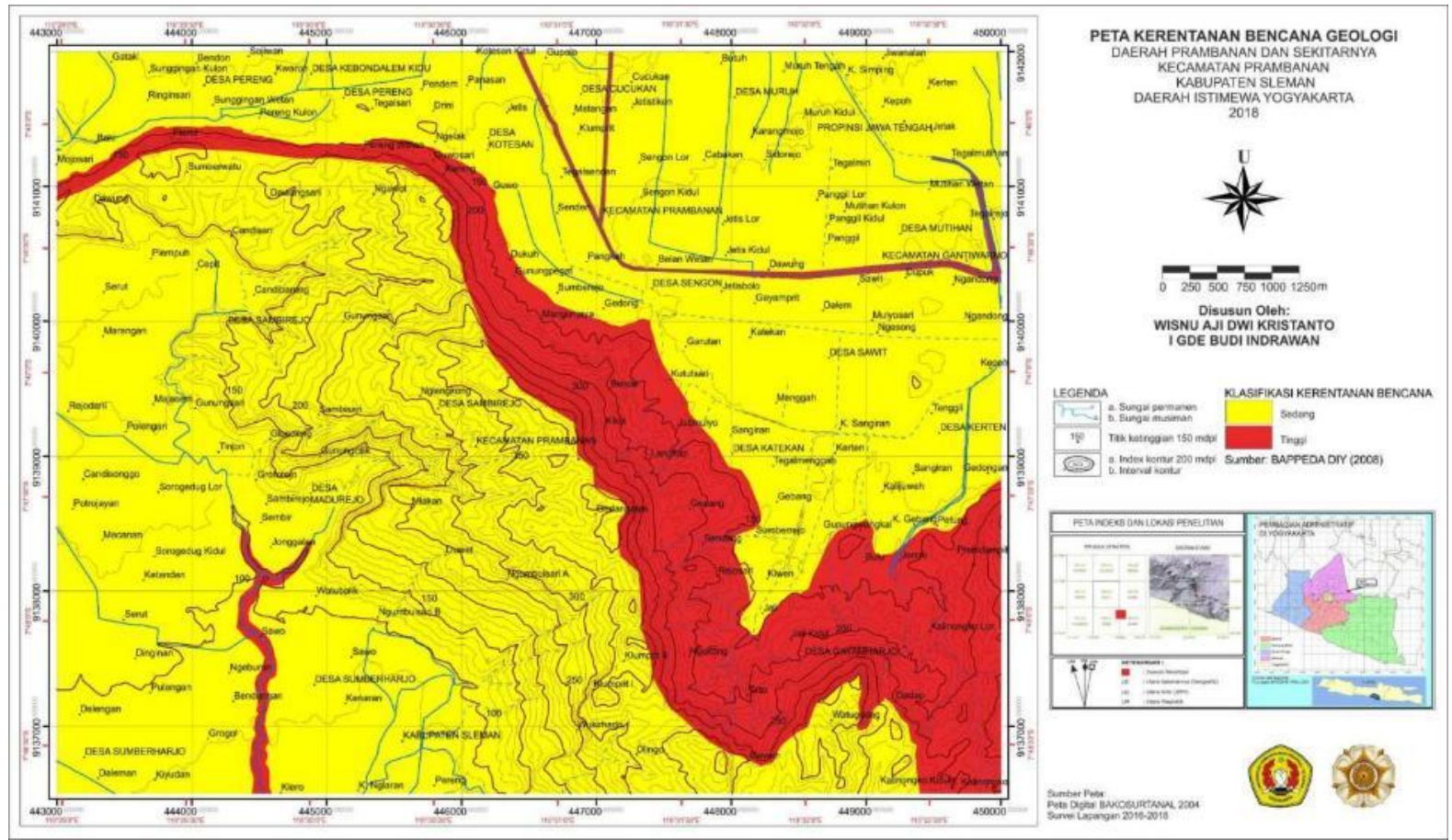

Gambar 7. Peta Kerentanan Bencana Geologi 
Daerah dengan kerentanan bencana geologi tinggi memiliki ancaman lebih dari satu macam ancaman bencana geologi. Daerah ini memiliki ancaman berupa kombinasi gempabumi, longsor, dan banjir. Sedangkan daerah dengan tingkat kerentanan sedang memiliki satu macam ancaman bencana geologi berupa gempabumi meliputi sebagian besar daerah penelitian yaitu perbukitan bagian barat, landaian utara sampai timur dan landaian barat.

\subsection{Analisis AHP}

Analisis kemampuan geologi teknik untuk pemukiman di daerah penelitian menggunakan metode AHP dan pengolahan dengan perangkat lunak Arc GIS 10 dari lima parameter yaitu: daya dukung batuan dan tanah, kemudahan penggalian, kemiringan lereng terhadap kemudahan pengerjaan konstruksi, kedalaman muka airtanah terhadap pondasi dan septic tank, dan kerentanan bencana geologi menghasilkan empat zona kemampuan geologi teknik untuk pemukiman yaitu: sangat rendah, rendah, menengah, dan tinggi yang dapat dilihat pada Gambar 8.

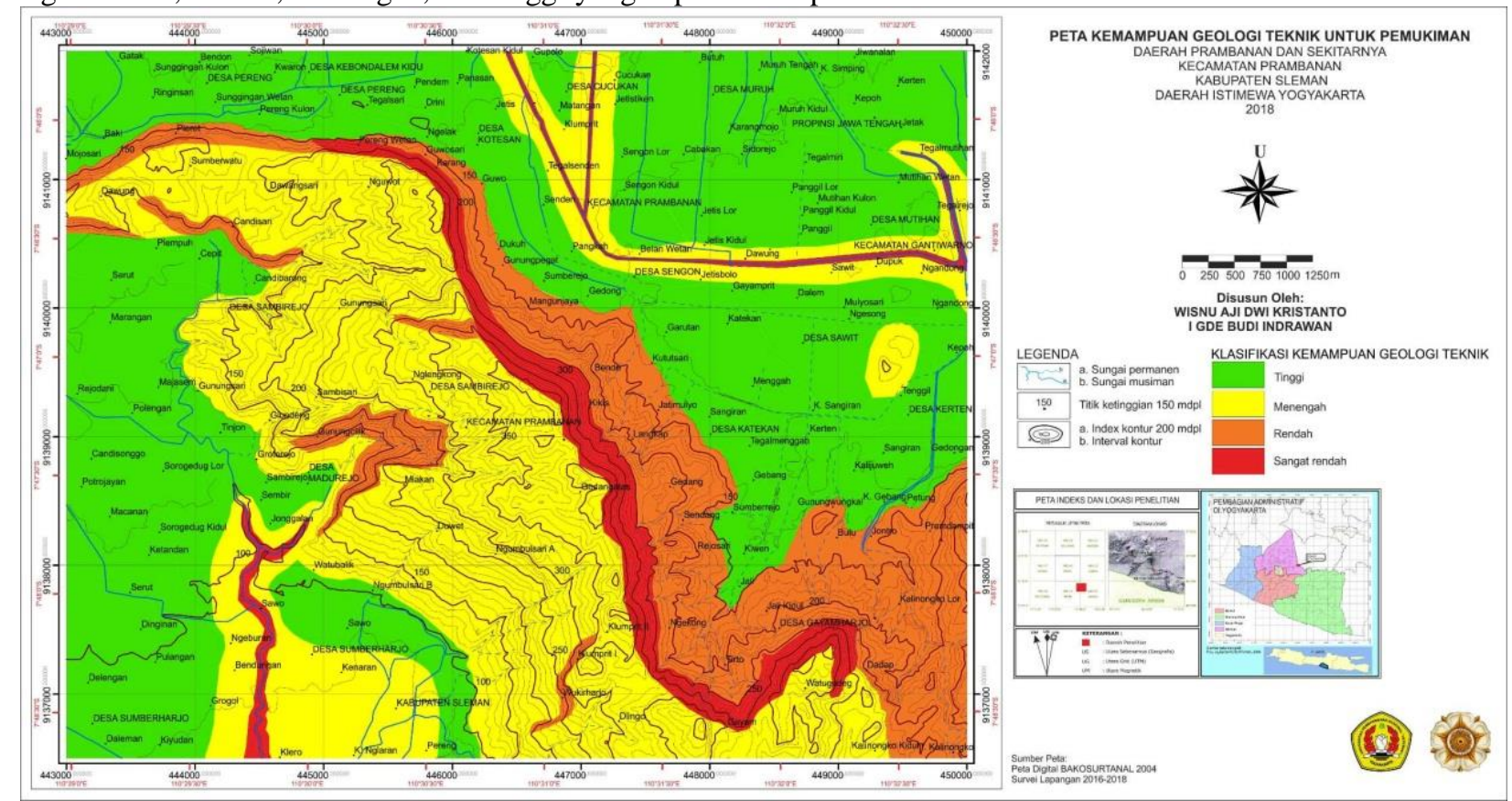

Gambar 8. Peta Kemampuan Geologi Teknik untuk Pemukiman

Zona kemampuan geologi teknik untuk pemukiman tinggi meliputi 36\% luas wilayah daerah penelitian yang menempati daerah landaian bagian utara, timur, dan barat daerah penelitian. Zona kemampuan geologi teknik untuk pemukiman tinggi merupakan zona yang paling direkomendasikan untuk dikembangkan menjadi wilayah pemukiman karena memiliki karakteristik geologi teknik yang baik untuk pondasi bangunan dan mudah untuk dikerjakan dengan kondisi: daya dukung batuan dan tanah untuk rumah sederhana lebih dari $1964 \mathrm{~kg} / \mathrm{m}^{2}$, kemiringan lereng $<8^{\circ}$, kemudahan penggalian mudah digali, kedalaman muka airtanah $>3$ meter, dan kerentanan bencana geologi sedang.

Zona kemampuan geologi teknik untuk pemukiman menengah meliputi $32 \%$ luas wilayah daerah penelitian yang menempati daerah perbukitan bagian barat dan selatan serta daerah dataran sekitar sungai besar. Zona kemampuan geologi teknik untuk pemukiman menengah merupakan zona yang cukup baik untuk dikembangkan menjadi wilayah pemukiman namun memerlukan penyelidikan detail sebelum dikembangkan menjadi wilayah pemukiman karena disamping zona ini memiliki daya dukung batuan dan tanah untuk rumah sederhana lebih dari $1964 \mathrm{~kg} / \mathrm{m}^{2} \mathrm{dan}$ kedalaman muka airtanah $>3$ meter di daerah perbukitan, zona ini juga memiliki kemiringan lereng $0^{\circ}-30^{\circ}$, kemudahan penggalian sulit digali hingga memerlukan peledakan, kedalaman muka airtanah di daerah sekitar sungai besar 1-3 m, serta kerentanan bencana geologi sedang. Penyelidikan detail perlu dilakukan terutama pada parameter yang dibawah standar peruntukan kemampuan geologi teknik untuk pemukiman sebagai peringatan sebelum dikembangkan menjadi wilayah pemukiman.

Zona kemampuan geologi teknik untuk pemukiman rendah meliputi $20 \%$ luas wilayah daerah penelitian yang menempati daerah sebagian gawir dan lereng sebelah timur. Zona kemampuan geologi teknik untuk pemukiman rendah merupakan zona yang tidak disarankan namun diijinkan untuk dikembangkan menjadi wilayah pemukiman dengan penyelidikan detail dan pekerjaan rekayasa terlebih dahulu sebelum dikembangkan menjadi wilayah pemukiman dikarenakan meskipun zona ini memiliki daya dukung batuan dan tanah untuk rumah sederhana lebih dari $1964 \mathrm{~kg} / \mathrm{m}^{2}$ dan kedalaman muka airtanah >3 meter, zona ini juga memiliki tingkat kerentanan bencana geologi yang tinggi terutama bencana longsor untuk daerah lereng sebelah timur dengan kemiringan $>30^{\circ}$. Penyelidikan detail perlu 
dilakukan terutama pada parameter yang dibawah standar peruntukan kemampuan geologi teknik untuk pemukiman serta pekerjaan rekayasa untuk meningkatkan kemampuan geologi teknik.

Zona kemampuan geologi teknik untuk pemukiman sangat rendah meliputi $12 \%$ luas wilayah daerah penelitian yang menempati daerah gawir sebelah timur dan sepanjang aliran sungai besar. Zona ini tidak diijinkan dan harus dihindari untuk dikembangkan menjadi wilayah pemukiman karena memiliki karakteristik geologi teknik yang buruk dan kerentanan bencana longsor dan banjir tinggi.

\section{KESIMPULAN}

Daerah perbukitan memiliki nilai kemampuan geologi teknik untuk pemukiman sangat rendah, rendah dan menengah, sedangkan daerah dataran memiliki nilai kemampuan geologi teknik untuk pemukiman tinggi pada sebagian besar area, menengah di daerah sekitar sungai besar, dan kemampuan geologi teknik sangat rendah untuk daerah sepanjang sungai besar. Metode pembuatan peta kemampuan geologi teknik untuk pemukiman ini dapat digunakan sebagai acuan untuk kasus serupa didaerah lain dengan penyesuaian kerentanan bencana geologi di daerah tersebut.

\section{UCAPAN TERIMAKASIH}

Ucapan terima kasih penulis sampaikan kepada Pemerintah Kecamatan Prambanan, tokoh masyarakat dan masyarakat setempat yang telah mengijinkan penelitian diwilayahnya.

\section{DAFTAR PUSTAKA}

Badan Pusat Statistik Daerah Istimewa Yogyakarta. (2015). Daerah Istimewa Yogyakarta dalam Angka 2015. BPS Daerah Istimewa Yogyakarta. Yogyakarta.

Badan Pusat Statistik Kabupaten Sleman. (2013). Kabupaten Sleman dalam Angka 2013. BPS Kabupaten Sleman. Yogyakarta.

BAKOSURTANAL. (2004). Peta Digital Jawa Tengah. Badan Koordinasi Survei dan Pemetaan Nasional, Cibinong.

BAPPEDA DIY. (2008). Profil Kebencanaan Provinsi Daerah Istimewa Yogyakarta. Badan Perencanaan Daerah, Provinsi Daerah Istimewa Yogyakarta.

Departemen Pekerjaan Umum. (1987). Pedoman Perencanaan Pembebanan Untuk Rumah dan Gedung. Yayasan Badan Penerbit PU, Jakarta.

Gurocak, Z., Alemdag, S., \& Zaman, M. M. (2008). Rock slope stability and excavatability assessment of rocks at the Kapikaya dam site, Turkey. Engineering Geology. https://doi.org/10.1016/j.enggeo.2007.08.005

Kristanto, W. A. D. Indrawan, I. G. B. (2018). Karakteristik Geologi Teknik Daerah Prambanan Dan Sekitarnya, Kecamatan Prambanan, Kabupaten Sleman, Daerah Istimewa Yogyakarta. KURVATEK. 3(2), 21-29. https://doi.org/10.33579/krvtk.v3i2.755

Kristanto, W. A. D., Astuti, F. A., Nugroho, N. E., \& Febriyanti, S. V. (2020). Sebaran Daerah Sulit Airtanah Berdasarkan Kondisi Geologi Daerah Perbukitan Kecamatan Prambanan, Sleman, Yogyakarta. Jurnal Sains \& Teknologi Lingkungan (JSTL). 12(1), 68-83. https://journal.uii.ac.id/JSTL/article/view/14543

Nugroho, N. E., Kristanto, W. A. D. (2020). Kajian Tingkat Risiko Tanah Longsor Desa Hargomulyo, Kecamatan Kokap, Kabupaten Kulonprogo. Jurnal Ilmiah Lingkungan Kebumian (JILK). 1(2), 9-25. http://jurnal.upnyk.ac.id/index.php/kebumian/article/view/3281

Saaty, T. L. (1977). A scaling method for priorities in hierarchical structures. Journal of Mathematical Psychology. 15. https://doi.org/10.1016/0022-2496(77)90033-5. hal. 234-281 